\title{
Exploring a model for finding meaning in the changing world of work (Part 3: Meaning as framing context)
}

\begin{tabular}{|c|c|}
\hline $\begin{array}{l}\text { Authors: } \\
\text { Daniel H. Bur } \\
\text { Freddie Crous } \\
\text { Gert Roodt }^{1}\end{array}$ & $e^{1,2}$ \\
\hline \multicolumn{2}{|c|}{$\begin{array}{l}\text { Affiliations: } \\
{ }^{1} \text { Department of Industrial } \\
\text { Psychology and People } \\
\text { Management, University of } \\
\text { Johannesburg, South Africa }\end{array}$} \\
\hline \multicolumn{2}{|c|}{$\begin{array}{l}{ }^{2} \text { Accenture South Africa, } \\
\text { Johannesburg, South Africa }\end{array}$} \\
\hline \multicolumn{2}{|c|}{$\begin{array}{l}\text { Correspondence to: } \\
\text { Gert Roodt }\end{array}$} \\
\hline \multicolumn{2}{|c|}{$\begin{array}{l}\text { Email: } \\
\text { groodt@uj.ac.za }\end{array}$} \\
\hline \multicolumn{2}{|c|}{$\begin{array}{l}\text { PO Box 524, Auckland Park } \\
\text { 2006, South Africa }\end{array}$} \\
\hline \multicolumn{2}{|c|}{$\begin{array}{l}\text { Received: } 04 \text { Oct. } 2011 \\
\text { Accepted: } 14 \text { Sept. } 2012 \\
\text { Published: } 20 \text { Mar. } 2013\end{array}$} \\
\hline \multicolumn{2}{|c|}{$\begin{array}{l}\text { How to cite this article: } \\
\text { Burger, D.H., Crous, F., \& } \\
\text { Roodt, G. (2013). Exploring } \\
\text { a model for finding meaning } \\
\text { in the changing world of } \\
\text { work (Part 3: Meaning as } \\
\text { framing context). SA Journal } \\
\text { of Industrial Psychology/SA } \\
\text { Tydskrif vir Bedryfsielkunde, } \\
\text { 39(2), Art. \#1022, } 10 \text { pages. } \\
\text { http://dx.doi.org/10.4102/ } \\
\text { sajip.v39i2.1022 }\end{array}$} \\
\hline \multicolumn{2}{|c|}{$\begin{array}{l}\text { Note: } \\
\text { This article is Part } 3 \text { of a } \\
\text { series of three articles by } \\
\text { the same authors. }\end{array}$} \\
\hline \multicolumn{2}{|c|}{$\begin{array}{l}\text { Copyright: } \\
\text { (C) 2013. The Authors. } \\
\text { Licensee: AOSIS } \\
\text { OpenJournals. This work } \\
\text { is licensed under the } \\
\text { Creative Commons } \\
\text { Attribution License. }\end{array}$} \\
\hline \multicolumn{2}{|l|}{ Read online: } \\
\hline 回的国 & $\begin{array}{l}\text { Scan this QR } \\
\text { code with your } \\
\text { smart phone or } \\
\text { mobile device } \\
\text { to read online. }\end{array}$ \\
\hline
\end{tabular}

Orientation: This article, the final in a series of three papers, locates organisational change, specifically within the context of individuals' experience of 'meaning', as conceptualised in Viktor Frankl's logotherapy.

Research purpose: The purpose of this theoretical paper is to investigate the context of meaning in organisational change by exploring the relationship between meaning and change.

Motivation for the study: Although literature on change management is available in abundance, very little research has been focussed on the micro-level issues pertaining to organisational change, and virtually no research relating to the 'existential meaning' context of such change could be found.

Research design, approach and method: The study was conducted by means of a review of literature, guided by the theoretical perspectives of logotherapy.

Main findings: Whilst systems to which individuals traditionally turned for meaning decline, organisations become increasingly important for employees' experience of meaning. As organisational change threatens such meaning, resistance to change may occur, which inhibits organisations' ability to change. Logotherapy provides a useful framework for understanding this meaning context, which could be utilised to inform frameworks to guide change implementation more successfully.

Practical and managerial implications: An understanding of the role that meaning can play in causing - and hence reducing - resistance to change may be of great value to organisations attempting to implement change initiatives.

Contribution: The value-add of the article is grounded on its exploration of the relatively uncharted territory of how the experience of meaning by employees may impact organisational change. This article therefore provides a novel perspective for conceptualising change. In addition, it suggests specific recommendations for utilising an understanding of the meaningchange relationship with the objective of optimising change initiatives.

\section{Introduction}

The need for continuous organisational change in contemporary environments has become common rhetoric in both management and academic literature - an omnipresent topic in 'books, practitioner or academic journals' (Washington \& Hacker, 2005, p. 400). Burnes (2003) maintained that in current turbulent environments, organisational change is one of the most critical and pertinent challenges organisations need to address. Research has shown that, whilst in 1978 organisations needed 'major change every four or five years', 'change has become a way of life in today's organizations' (Hacker \& Washington, 2004, p. 52). As business environments become more competitive and complex, sustaining a competitive advantage demands increased organisational flexibility, which is essential for the adaptation to factors such as increased competition, globalisation and continuous technological developments (Carbery \& Garavan, 2005; Gil, Rico, Alcover \& Barrasa, 2005; Jime'nez-Jime'nez \& Sanz-Valle, 2005; Tetenbaum, 1998).

Therefore, it is suggested that in order to secure survival, organisations 'need to decide not whether to change, but when and how to make it occur more successfully' [emphasis in original] (Newstrom \& Davis, 1997, p. 398). Change is so pervasive that it has become part of normal organisational life, rather than an exceptional phenomenon (McGuinness \& Morgan, 2005), whereas the management of change is regarded as a core organisational and leadership skill (Ahn, Adamson \& Dornbusch, 2004; Burnes, 1996; 2003; Counsell, Tennant \& Neailey, 2005). Furthermore, it is often argued that incremental efforts are frequently not sufficient - survival increasingly depends upon transformational changes (Francis, Bessant \& Hobday, 2003; Johnson, 2004). Change needs to be undertaken continuously (McGuinness \& Morgan, 2005) and with ever-improving effectiveness (Pfeifer, Schmitt \& Voigt, 2005). 
Organisational change can be defined as the significant alteration of any number of elements in the organisation, including behaviour, structures, technology, processes and/or strategy (Burger, 2007). Examples of large-scale organisational changes include downsizing (Fiorito, Bozeman, Young \& Meurs, 2007; Hellgren, Näswall \& Sverker, 2005; McGreevy, 2003a), restructuring (Ambrose, 1996; Carbery \& Garavan, 2005; Watson, 2003), business process reengineering (Hammer, 1996; Hammer \& Champy, 1993), mergers and acquisitions (M\&As) (Cartwright \& Cooper, 1994, 1995).

Washington and Hacker (2005) argue that much of the literature relating to organisational change focuses particularly on reasons for the failure of change initiatives. In this regard, research shows that the capacity of the organisation's people to accommodate change, may significantly constrain transformation (Ghoshal \& Bartlett, 1996; Karp, 2004). Whereas the field of organisation development has made significant contributions in assisting organisations to develop the change capacity of their employees (e.g. Cummings \& Worley, 2001; French \& Bell, 1999), it can be argued that most popular change frameworks have not adequately addressed a fundamental human question - the individual search for meaning in life (see Burger, 2007; Burger, Crous \& Roodt, 2008). The question of meaning in life, which Frankl (1978, 1984) calls the 'noölogical' (or spiritual) dimension of human existence, will be shown in this article to have a potentially fundamental impact on the effectiveness of organisational change efforts. This focus differs substantially from traditional approaches where the emphasis is on aspects like organisational processes to manage individual behaviours in order to achieve a desired outcome.

This apparent oversight on the part of change perspectives then warrants, or calls for, the exploration of promising novel approaches for contextualising and managing organisational change. Subsequently, the research question to be approached in this article is: How does meaning constitute a framing context for organisational change? This research question is aimed at exploring the role of every individual's unique experience of meaning in life within the setting of organisational change and will be answered by researching two research assignments, namely (1) investigating the potential impact of organisational change on the individual's experience of meaning and (2) exploring the implications and repercussions of employee reactions to a threat to meaning in terms of the success of organisational change initiatives.

\section{Purpose of the study}

This article, the final one in a series of three, seeks to explore relatively uncharted territory of how an employee's experience of meaning in life may impact organisational change. It is not only proposed that change impacts the meaning that every individual experiences in his or her working environment, but also that meaning may influence the reaction of employees to change initiatives. The outcome of this investigation of meaning as a framing context for organisational change will be determined by firstly exploring the concept of meaning in life in general, and in work and organisations in particular. This will be followed by the problem statement, research objectives and motivation for the study, all of which relate to this potentially critical interaction between change and meaning. Following an overview of the research design, the literature review will explore the potential threat that organisational change poses to meaning found in or at work, together with the possible ramifications. Finally, in the discussion, the role that logotherapy and its underlying principles may play in assisting organisations in facilitating change will be briefly highlighted. These arguments will serve to elucidate the immense value that an understanding of the concept of meaning may have in constructing paradigms for change.

\section{Current theoretical perspectives}

\section{Logotherapy and the importance of meaning}

The term 'meaning' has received significant attention in literature on change, particularly with reference to the concept of sensemaking (e.g. Ayers, 2005; Bartunek, Rousseau, Rudolph \& De Palma, 2006; Bean \& Hamilton, 2006; Scroggins, 2006), providing a rich body of information for guiding practitioners in their efforts of driving change initiatives. For example, authors like Maitlis and Sonenshein (2010) found that organisational changes resemble crises in its impact on individual meaning (or sensemaking), holding vast implications regarding identity, expectations and emotions. However, the focus of this article is specifically on the concept of finding meaning in life in relation to the organisational and work context, rather than focusing on how individuals and groups make sense of changes in the organisation (i.e. interpretation of the meaning of the change).

Although meaning in life is assumed as critically important in both 'classic' existential theory and logotherapy (e.g. Frankl, 1984; Stevenson, 1987), theorists here have not been forthcoming in providing a unifying definition of what is meant by this term. Rather, it is generally described as a subjective condition $^{1}$ - that is, it varies from individual to individual and situation to situation - essential to individual well-being (e.g. Frankl, 1984, 1988; Hergenhahn, 1997; Stevenson, 1987; Yalom, 1980), with the emphasis on how such meaning can be found and the impact of failure to do so. Although a comprehensive exposition in this regard is beyond the scope of this article, the discussion below briefly outlines Frankl's views with regard to meaning in life.

Logotherapy maintains that meaning is the primary motivating force in the individual's life ${ }^{2}$, a concept denoted as the will to meaning (e.g. Frankl, 1984). This notion is well demonstrated by Weber (2000), who contended that:

We humans are purpose seekers, more defined by our ability to pursue purpose in diverse ways than by almost any other human trait ... Being purposive is our natural state, made evident by the unusual circumstances of being without purpose ... Purpose acts as motor, fuel, and steering for the human vehicle. (pp. 221-222)

1.In this regard, Franki (1988) distinguished between (1) ultimate meaning, referring to the spiritual belief or awareness that one is part of some form of order in the universe (Fabry, 1988), (2) specific meaning that is unique to the individual and (3) values, or 'meaning universals', represented by situations that are sufficiently similar to evoke similar responses from different individuals.

2.As opposed to, for example, self-actualisation in Maslow's theory. 
Logotherapy, which means 'therapy through meaning', is aimed at helping an individual to find such meaning, or purpose, in life (Fabry, 1987, 1988; Frankl, 1967, 1984, 1986, 1988, 1990, 1992, 2000a, 2000b). Discovering meaning will significantly improve one's quality of life (Greenstein \& Breitbart, 2000), irrespective of one's circumstances.

Frankl proposed that meaning is not created, but found through experiential, creative and attitudinal values (Frankl, 1967, 1978; Kausch \& Amer, 2007; Moomal, 1999; Southwick, Gilmartin, McDonough \& Morrissey, 2006). Creative values entail making a creative contribution to life, such as when one expresses oneself in one's work (Shantall, 1989). Support for this assumption is found in Csikszentmihalyi's (1996) belief that creativity 'is a central source of meaning in our lives' (p. 1), particularly as most things that define humanity result from creativity, and creative pursuits make people's lives feel more complete (see also Csikszentmihalyi, 1999). Similarly, Fromm believes that one way in which people transcend their natural existence is through creating (Viljoen, 1989), whereas Heidegger (in Gini \& Sullivan, 1993) proclaimed that 'you are your projects ... a person that cannot point to achievements does not, and cannot, feel like a full person' (p. 137).

Experiential values refer to one's direct experiences of beauty and love, as well as any other things that are good, true and authentic (Das, 1998; Shantall, 1989). These values may include relational factors such as developing and maintaining strong friendships and feeling part of a community. This is of particular significance if one considers Fromm's belief that despite one's need for individuality, commitment to others and to society is essential to avoid loneliness and isolation (Viljoen, 1989).

Finally, realising attitudinal values involves the attitude one takes towards a fate one cannot change (Frankl, 1967; 1978; 1984; 1986). Such unavoidable fate usually involves the socalled tragic triad of suffering, guilt and the transitoriness of human existence (Frankl, 1984; 1988; 2000a). Burger (2007) demonstrated that each of the components of the tragic triad could conceptually be tied to organisational change - an issue further explored later in this article. Failure to find meaning, or existential frustration, results in what Frankl (1984) termed the existential vacuum. This phenomenon is characterised by individuals trying to compensate for their lack of purpose in life by the single-minded pursuit of pleasure or power, for example, through workaholism, an obsessive striving for money or sexual compulsion (Dollarhide, 1997, Shantall, 1989). Moreover, the existential vacuum most often manifests in feelings of inner emptiness (Frankl, 1984; Fabry, 1987), states of boredom and apathy (Das, 1998, Frankl, 1984), and unquestioning conformity to the most dominant social trends (Das, 1998). This is akin to what Fromm $(1976,1993)$ called a 'having' orientation, where one is focused on owning things (property, people, status and so forth), as opposed to a 'being' orientation which resembles a focus on meaning in life.

Frankl (1984; 2000a) attributed existential frustration, also known as the existential vacuum, to a number of conditions. Firstly, the deterioration of traditional cornerstones such as the family, church, school and state (Fabry, 1987) and the variety of value orientations in contemporary societies (Das, 1998) constrain the availability of clear values to direct individual decisions and behaviour. Secondly, the 'tragic triad' outlined above often results in individuals questioning the meaningfulness of life (Frankl, 1984). Symptoms of the existential vacuum include boredom, apathy (Das, 1998, Frankl, 1984) and various psychopathologies (Moomal, 1999). If prolonged, this may result in 'noögenic neurosis' (Das, 1998; Shantall, 1989). Only through addressing one's ability to find meaning in life can these conditions be ameliorated (Frankl, 1984). As is demonstrated below, one's work and organisation may play a crucial role in this search for meaning.

\section{Understanding how meaning is found in the organisation}

All humans prefer meaningful work to meaningless work ... if work is meaninglessness, then life comes close to being meaningless. (Maslow, 1998, p. 39)

The question of meaning in work has steadily increased over the past few decades - one reason being the 'gradual undermining of many organisations and institutions that people have traditionally turned to for a sense of belonging (Heil, Bennis \& Stephens, 2000; p. 119). These institutions, which include the family, churches and communities, also used to provide one with meaning, affiliation, identity and support (Bartlett \& Ghoshal, 1994). Similarly, Morin (1995) postulates that 'as a result of the weakening of religious and spiritual systems', 'the question of the meaning of work' has become 'inevitable '(p. 56). It has been realised for a long time that the role of work goes beyond providing one with a paycheque - it impacts the individual's personal development, identity, self-esteem, and ultimately, meaning in life (e.g. Frances, 1995; Kets de Vries, 2001; McGreevy, 2003b; Pratt \& Ashforth, 2003; Rossouw, 2002). In this regard, Hall (1996) pointed out that:

there is evidence that the more meaning can be found in work, the more fulfilled a person can be ... the more this meaning is found at work, the more likely this positive experience is to spill over into the person's private life. (pp. 325-326)

Isaksen (2000, p. 88) defines meaning in work as 'an intrapsychological phenomenon that emerges in individual's interaction with his or her working environment' and 'concerns the reasons an individual has for working, what he or she seeks to accomplish by working, and the continuity that he or she experiences in work' - a 'purposefulness that makes life more comprehensible'. Finding meaning in work has been found to relate to concepts such as job involvement and flow, shown to increase work engagement and the associated motivation and commitment (May, Gilson \& Harter, 2004). Moreover, research shows that many individuals see meaningful work just as important as pay and job security (Steger, Pickering, Shin \& Dik, 2010). According to Wrzesniewski (2003), finding meaning in work is critically dependent upon three factors (see Figure 1):

- Firstly, the individual's 'internal' factors play a role that is, the person's personality and 'individual needs, demographic factors, and socio-economic background'. 


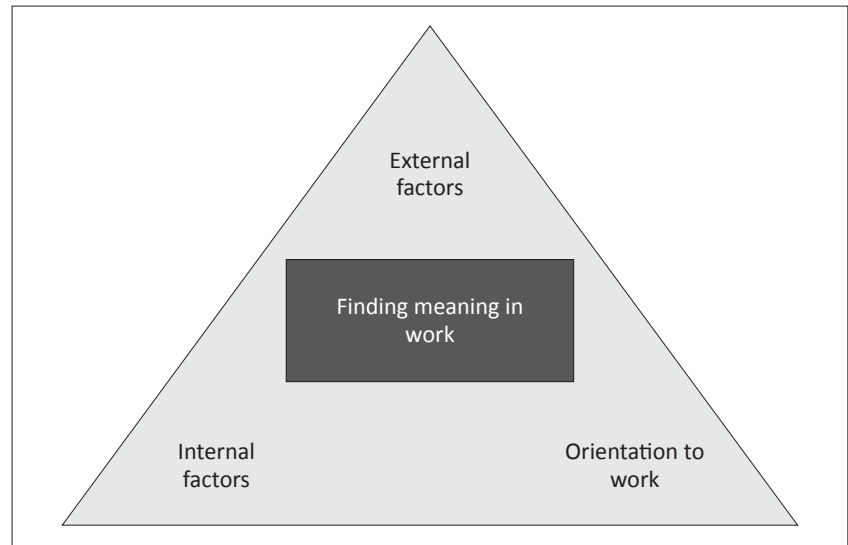

Source: Adapted from Wrzesniewski, A., Dutton, J., \& Debebe, G. (2003). Interpersonal sense making and the meaning of work. Research in Organisational Behavior, 25, 95-135. http:// dx.doi.org/10.1016/S0191-3085(03)25003-6

FIGURE 1: Determinants of how meaning is found in work.

- Secondly, external factors (i.e. the job and the wider organisational environment) are involved.

- Finally, the individual employee's orientation towards work, which 'helps to determine his or her thoughts, feelings, and behavioural attitude towards work' (p. 300), has a significant impact on whether they find meaning in work or not.

Pratt \& Ashforth (2003) distinguished between meaningfulness in work and meaningfulness at work. Finding meaning in work relates to the role that one performs or what one does at work. This clearly relates to Frankl's notion of creative values, shown earlier to involve finding meaning through creating. The extent to which one's role or job allows for such creative efforts may therefore substantially impact finding meaning in work: meaning which may be threatened in situations where change might result in a largely different role or job.

Meaningfulness at work, in turn, is found through one's sense of belonging: 'Finding meaning in whom one surrounds oneself with as part of organisational membership, and/or in the goals, values and beliefs that the organisation espouses' (Pratt \& Ashforth, 2003, p. 314). This is strongly supported by findings that one's interpersonal relationships and interactions in the organisational context have a substantial impact on one's experience of meaning, as well as how one makes sense of the world of work (Wrzesniewski, Dutton \& Debebe, 2003). Frankl's notion of experiential values, shown earlier to involve finding meaning through one's good and true experiences (e.g. in relationships), are clearly related directly to finding meaning at work. Organisational changes that may impact one's work context, an extreme example being the retrenchment of one's colleagues, may thus also impact this dimension of meaning.

The logotherapeutic notion of freedom of will in one's attitude toward one's circumstances is important in defining how meaning in work is found. To summarise, finding meaning in work is predominantly a function of one's attitudinal values (or how one frames one's work Wrzesniewski \& Dutton, 2001), more than that of the job itself or its context (external factors). In this regard, Pratt and Ashforth (2003, p. 311) pointed out that 'meaningfulness is necessarily subjective', varying substantially across contexts and is not a characteristic of the job. Wrzesniewski (2003), in turn, argues that one's relationship to one's job is more pertinent than the actual job. As a result, 'people can derive different kinds of meaning from almost any job or occupation' (p. 300), and 'even in the same job in the same organization, there are significant differences in how people make meaning of their work' (p. 302). This is believed to be true for even 'the most restricted and routine jobs' (Wrzesniewski \& Dutton, 2001, p. 179). In this regard, Frankl (1986) argued that:

the job at which one works is not what counts, but rather the manner in which one does the work. It does not lie with the occupation, but always with us, whether those elements of the personal and the specific which constitute the uniqueness of our existence are expressed in the work and thus make life meaningful ... The indispensability and irreplaceability, the singularity and uniqueness issue from the person, depend on who is doing the work and on the manner in which he is doing it, not the job itself (pp. 118-119).

\section{Problem statement and research objectives}

[Organisational changes] have created a growing feeling of cynicism, ultimately eroding people's sense of meaning. (Cooper, 2007, p. 29)

The aforementioned arguments indicate that organisations today play a central role in the individual's search for meaning in life. However, given the incessant need for change, it stands to reason that in some instances, those factors that lead to meaning in or at work may come under threat. Failure on the part of the individual employee to adapt to such circumstances will then translate into organisational change contributing to meaninglessness or, in Frankl's terms, existential frustration and the existential vacuum. Subsequently, the problem statement central to this article is discussed below.

\section{How does meaning constitute a framing context for organisational change?}

Following this problem statement, two research objectives need to be achieved:

- Investigation of potential impact of organisational change on the individual's experience of meaning. Exploration of the implications and repercussions of employee reactions when meaning is threatened, with regard to the success of organisational change initiatives.

\section{Rationale or value-add of the study}

Despite the apparent abundance of literature in the sphere of organisational change, Vakola, Tsaousis and Nikolaou (2004) point out that change management research is predominantly focused on 'organisational factors', and as a result, 'person-oriented issues' are neglected (p. 88). This is highly problematic, as research clearly emphasises peoplerelated issues to be the primary reason for the failure of organisational change efforts (Atkinson, 2005; Cartwright \& Cooper, 1994; Chawla \& Kelloway, 2004; Karp, 2004; 
Roxburgh, 2003; Smith, 2005a; 2005b; Rashid, Sambasivan \& Rahman, 2004; Vakola et al., 2004; Worrall \& Cooper, 2004). Aggravating this problem even further, is the fact that existing research on the people aspects of organisational change has to some extent also neglected a focus on the micro-level of organisational change (Vakola et al., 2004, p. 88) - that is, the individual - who is the focus of logotherapy.

Virtually no research relating directly to the problem statement and research objectives of this study, as stated above, could be found in the literature. This not only includes South African (SA) research, but also research in the international domain. In fact, it was established that research concerning the application of logotherapy in the organisational context in general is very limited, with the exception of some articles published primarily in dedicated journals such as The International Forum for Logotherapy. It is therefore apparent that a gap exists in the literature with regard to the importance of meaning in life within the context of organisational change, as addressed in this study. Given the impact that a lack of meaning can have - firstly in terms of the well-being of the individual employee and secondly concerning the outcomes of change initiatives (see discussion in literature review section below) - these perspectives are critical in facilitating a better understanding of organisational change.

\section{Research design \\ Research approach}

As has been alluded to throughout this paper, the specific theoretical perspective or school of thought, guiding the arguments presented here is logotherapy. Logotherapy was developed by Viktor Frankl - an Austrian psychiatrist and neurologist and Holocaust survivor. His Man's Search for Meaning, in which he conveyed both his experiences in the Nazi concentration camps and an overview of his 'Third Viennese School of Psychotherapy'3 (Frankl, 2000b), is his most famous work and has sold more than nine million copies in 23 languages (Havenga \& Coetzer, 1997; Washburn, 1998). The primary motivation for utilising this approach relates to the authority of logotherapy in general, and Frankl in particular, in conceptualising and operationalising meaning in life.

\section{Research method}

A literature review was adopted as the research strategy for this article. The rationale for choosing this approach rests upon its utility in acquiring sufficient knowledge of the subject area intended for study, along with facilitating comprehension of the significance of work already conducted in the field. This knowledge provides a perspective on how the subject has developed and become established (Hart, 2005). What is more, literature reviews help researchers to highlight research possibilities that have been implicitly overlooked in research to date and to generate and refine research ideas and objectives (Saunders, Lewis \& Thornhill, 2007).

3.The first being Freud's psychoanalysis, and the second Adler's individual psychology

\section{Targeted body of literature}

Literature gathered pertained to firstly, logotherapy and the logotherapeutic conceptualisation of meaning in life; secondly, organisational change and its impact on individual employees; thirdly, resistance to change and finally, the role of meaning in organisational change. However, as was noted earlier, research pertaining directly to the research question is exceptionally sparse $e^{4}$.

Portals utilised were those available to the University of Johannesburg, mostly including online international journals, which were searched by means of engines such as EbscoHost, Infotrac, and Emerald. As far as possible, local publications - as well as European articles - were utilised to get a wider perspective and prevent a predominantly American point of view. This enabled the use of a wide literature base as a starting point and ensured that adequate data would be surveyed to sufficiently support conclusions made.

Information about logotherapy was mostly gathered directly from Frankl's books (e.g. Frankl, 1967; 1978; 1984; 1986; 1988; 2000a; 2000b) and related articles. The latter included both internationally published books (e.g. Fabry, 1987; 1988) and local publications (e.g. Shantall, 1989).

\section{Gathering the data}

The selection of data was guided by the objectives of this article:

- Firstly, specific research pertaining to the role of meaning in organisational change was gathered and selected.

- Secondly, Frankl's frameworks for finding meaning in life and the consequences of failing to do so were applied to an organisational change context to identify potential ways in which organisational change can impact the individual's experience of purpose in life.

- Thirdly, bodies of literature specifically pertaining to resistance to change were explored to identify linkages between threats to meaning and the emergence of such resistance.

\section{Analysis of the data}

As indicated before, the analysis and categorisation of data were guided by the relationship between meaning and organisational change and the potential implications regarding the management of change initiatives. Firstly, the role of organisations in the finding of meaning, or purpose, by individuals was investigated. Secondly, the potential impact of organisational change on such experiences of meaning was explored. Thirdly, the potential role of the impact of organisational change in employee resistance to change was determined. This process was guided throughout by Frankl's logotherapeutic principles.

\section{Presentation of the data}

The results of the study are presented in two sections. Firstly, Frankl's concept of an existential vacuum is applied within

4.A literature search reveals the majority of articles related to 'meaning and organisational change' address the concept from a social constructionist framework. 
an organisational context to illustrate the impact that change can have on the individual's experience of meaning. This is accomplished by drawing parallels between the major causes of the existential vacuum and characteristics of organisational change. Secondly, a brief overview is presented of how the threat to one's experience of meaning inherent in organisational change can contribute to the emergence of resistance to change, with specific emphasis on the element of personal loss associated with change initiatives.

\section{Results}

\section{Organisational change as a threat to meaning: The existential vacuum}

As was noted earlier, Frankl maintained that the existential vacuum results primarily from the deterioration of traditional values, the increasing diversity of value orientations in present-day cultures, and the tragic triad ${ }^{5}$. In this section, it will be argued that these factors may also be present within the changing organisation, thus inhibiting the individual's ability to find meaning in life.

According to Frankl (1984), the evolutionary loss of human instincts and drives has resulted in individuals turning to values as a guide for their behaviours. However, the traditional role of these values in finding meaning is also rapidly declining, thereby constituting a major contributor to the individual's experience of an existential vacuum. This phenomenon is also apparent in changing organisations, as 'the rules that have guided how we operate no longer work', and there is no longer a 'clear set of guidelines, rules, or directions for action' (Luthans \& Avolio, 2003, p. 242).

The existential vacuum is further aggravated by the multiplicity of value orientations in contemporary societies (Das, 1998), a cause also present in the changing organisation. Authors such as Byars and Rue (2000), Cappelli (1999), Greenhaus, Callanan and Godshalk (2000), and Robbins, Odendaal and Roodt (2003) contended that an ever-increasing phenomenon in the workplace is the changing demographics of the workforce in terms of aspects such as race, gender, culture and age. In South Africa, organisations are increasingly faced with having to develop strategies to effectively manage culturally diverse workforces (Naidu \& Van der Walt, 2005), particularly because of the Employment Equity Act, 55 of 1998, increasing the diversity of the workplace. Such diversity then results in a workplace characterised by an 'absence of shared histories, values, and experiences' (Rossouw \& Bews, 2002, p. 146), which may obstruct one's commitment to a specific value orientation.

The tragic triad may also emerge as a result of organisational change. Not only may suffering be related to the negative experiences associated with these changes, but guilt may also occur when one's potential is frustrated because of the

5.Frankl (1984) also noted the loss of human instincts and drives due to evolution as a significant contributor to the existential vacuum. However, because it may be as a significant contributor to the existential vacuum. However, because it may be regardless of their employment status, the focus of the discussion will be on the remaining three elements. consequences of organisational change, such as the career plateau and disengagement (see Burger, 2007). Finally, Frankl's work on unemployment $(1978 ; 1984)$ indicated strong parallels between this state and one's awareness of the transitoriness of one's existence. This proposition was also strongly supported in the_literature (e.g. Cartwright \& Cooper, 1994; Dalton, 1989; Maslow, 1998; Rifkin, 1995).

The above-mentioned arguments indicated that organisational change may pose a real threat to the meaning that individuals experience in or at work - so much so that an existential vacuum may arise for some employees. Given its importance, it may be assumed that individuals may resist change to protect or preserve the meaning they have found in or at work. Moreover, the meaninglessness of the existential vacuum is strongly related to alienation and disengagement, issues shown to result in reduced motivation and commitment amongst employees (May et al., 2004). Similarly, Heine, Proulx, and Vohs (2006) found that when people's need for meaning is threatened, they can 'reaffirm meaning in domains that are different from the domain in which the threat occurred' (p. 88). Thus, where work as a source of meaning is disrupted, individuals may, rather than attempting to re-establish meaning in this context, search for purpose in other areas of their lives. Whereas this may not constitute active change resistance, the substantial implication is that these areas may be far removed from the reaching of organisational goals. Moreover, the disruption of individual meaning in the working environment may result in disengagement of individuals from the objectives to be achieved through organisational change efforts.

\section{The threat to meaning and resistance to change}

In resistance, people try to preserve their sense of meaning and identity, by retaining familiar ways of doing things... the resistance phase is about loss: loss of control, familiar attachments, community, and structures ... During resistance, people feel worse, stress is higher and performance is at lower levels. (Burnes \& James, 1994, pp. 171-172)

Resistance to change involves employee attitudes that manifest in behaviours (such as reduced output, strikes, sabotage and absenteeism) (Chawla \& Kelloway, 2004; Lawrence, 1970; Nguyen-Huy, 2000; Wanberg \& Banas, 2000; Young, 2000) meant to 'discredit, delay or prevent' change implementation (Newstrom \& Davis, 1997, p. 403). It encompasses 'a psychological rejection of the need for the change' (Chawla \& Kelloway, 2004, p. 485). These attitudes are very difficult to change as they become 'deeply ingrained in organizations and people' (Sirkin, Keenan \& Jackson, 2005 , p. 2). Resistance to change is a leading cause for the failure of change efforts. Kotter and Schlesinger (1979) stated that resistance to change could possibly emerge when individuals fear that they may lose something meaningful because of organisational change. This could include the loss of security and stability (Chreim, 2006; Ugboro, 2006), status (Proctor \& Doukakis, 2003), competence or self-efficacy (Chreim, 2006) and the vision and values of the status quo (Trader-Leigh, 2002). Abel and Sementelli (2005) pointed out that organisational change often requires employees to 
change their values, attitudes, and beliefs; factors already determined to be central to the individual's experience of meaning in life. Similarly, Frances (1995, p. 61) argued that organisational change might threaten 'the core issues of our personal identity and the meaning we give to our work and our occupational choice'.

\section{Discussion}

The objective of this study was investigating the role of meaning as a framing context for organisational change. Special attention was given to the role of organisational change in creating an existential vacuum, that, when experienced by employees, may result in resistance to change. It was found that this is a novel perspective on framing change that has the potential of making significant contributions toward the successful facilitation of change initiatives. The review of the literature suggested that organisational change may have a significant impact on the individual's experience of meaning. In particular it was found that the emergence of an existential vacuum in the lives of employees may be prompted by organisational change. As a result, meaning and the ability to find such meaning, are fundamentally frustrated. A resistance to change, in an effort to conserve this meaning, may threaten the success of the change initiatives. In this regard, Burger (2007) and Burger et al. (2008) reported an empirically verified relationship between the experience of meaning and resistance to change. (2008). Their findings largely underscore the proposition that meaning should be considered a critical variable in framing the context of change.

Despite the aforementioned, it should be kept in mind that 'psychology's first law is that people are different' (Cascio, 1998 , p. 2), implying that individual differences exist as to how employees experience and react to changes. Bovey and Hede (2001) contended that individuals' 'ability and willingness' to adapt to organisational changes, often vary significantly (p. 534): what one individual may see as a barrier, another may interpret as an opportunity (Kinnear \& Roodt, 1998). Similarly, Smith (2005b) stated that:

It is often popularly held that people, particularly those working in established and settled organisations, will tend to resist change. That is an oversimplification. Individuals and groups can and do react to change in a range of ways. For some change and transition are exciting and stimulating - they cannot wait to make the changes and get to the new state of things. For others change is deeply unsettling and a threat to their values and sense of worth - something to be resisted at all costs. (p. 153)

Therefore, although the experience of meaning may appear to be threatened to some, resulting in 'resistance to change' behaviours, others may display readiness for change. These individuals may find meaning in the change, or the postchange situation, resulting in them-supporting change initiatives (Burger, 2007).

Readiness for change is considered the polar opposite of resistance to change and is viewed as critical in effective change facilitation. According to Chapman (2002), organisational change is only possible when employees display readiness for change, accept the need to change, and display 'a positive willingness to engage in processes that may be difficult and challenging' (p. 23). According to Armenakis, Harris and Mossholder (1993), readiness for change is:

reflected in organizational members' beliefs, attitudes and intentions regarding the extent to which changes are needed and the organization's capacity to successfully make those changes... creating readiness for change involves proactive attempts ... to influence the beliefs, attitudes, intentions, and ultimately the behavior of the change target. At its core, the creation of readiness for change involves changing individual cognitions across a set of employees. (pp. 282-283)

A possible moderating factor in the relationship between meaning and change is the extent to which individuals see their work as a 'calling' - that is, the notion that work can be 'both meaningful and provide a broader sense of meaning in a person's life' (Steger et al., 2010, p. 93). Research by Wrzesniewski, McCauley \& Rozin (1997) found that most individuals view their work as a 'job' - something that is required to support one's life and interests but not necessarily something positive; a 'career', which is focussed on one's progression throughout one's work life, or a 'calling', where one believes that one is doing useful work and making a larger contribution (i.e. doing 'meaningful' work). The latter have been found to show higher satisfaction with both life and work, than those who view their work as jobs or careers - even when extraneous variables such as income, education and occupation are controlled (Wrzesniewski et al., 1997). They have also been found to attribute greater value to their work and display more effective collaboration with others (Steger et al., 2010). It could be suggested that organisational change may potentially impact those factors, leading to one seeing work as a calling, either threatening or enhancing them, which could ultimately influence the attitude one displays towards the change initiatives.

Given the implications of the discussions above, it is apparent that change practitioners and organisations need to take cognisance of the importance of the construct of meaning in the lives of employees, as well as the potential impact thereof. This pertains not only to employees' attitudes towards organisational change initiatives (i.e. resistance to change, or its polar opposite, readiness for change), but also to the business impact of individuals' experience of meaning. For example, research 'has shown that a sense of meaning is an important correlate of work motivation and positive work attitudes' (Schlecter \& Engelbrecht, 2006, p. 4). Meaning is also related to organisational commitment (Markow \& Klenke, 2005) which, in turn, relates to change readiness (Bennett \& Durkin, 2000; Nijhof, De Jong \& Beukhof, 1998). Moreover, individuals are more likely to change if the organisation relates the need for change to 'something they care about in the form of a deeper meaning or a higher purpose' (Karp, 2004, p. 353).

Organisations should therefore realise that the individual employee's experience of meaning within the work context may, in the long run, be instrumental in their survival and, 


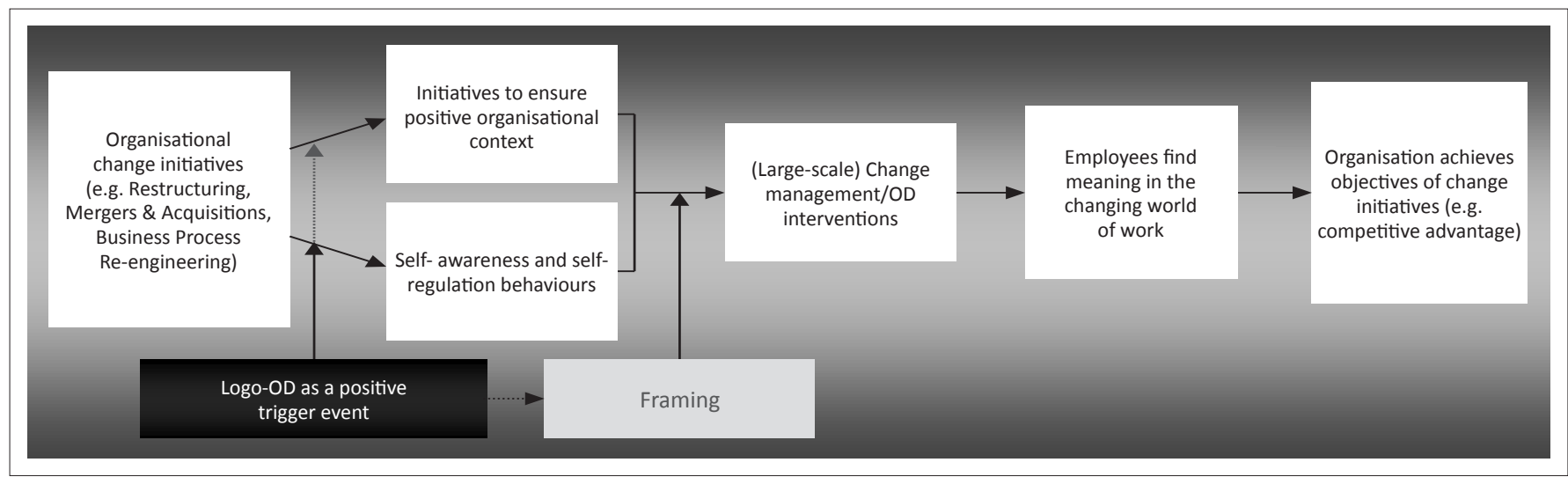

FIGURE 2: A framework for leveraging the meaning context to facilitate organisational change.

where possible, they should implement interventions for using this knowledge to the full benefit of their organisation. One potential framework for utilising the meaning context to leverage organisational change, was provided by Burger (2007) and is graphically represented in Figure 2 above. This framework, adapted from a model for authentic leadership development proposed by Avolio and Luthans (2006), indicates how logotherapeutic principles can be utilised to optimise change effectiveness. Three crucial elements are mentioned here, namely applying Logo-OD as a positive trigger event for organisational change, creating a positive organisational context and framing organisational change based on logotherapeutic principles (for further discussion, see Burger, 2007; Burger et al., 2008).

\section{Limitations of the study}

The primary limitation of this study is that, based on the use of a literature review methodology, no empirical evidence of causal relationships between the experience of meaning and organisational change could be established. Furthermore, although Burger (2007) and Burger et al. (2008) reported evidence to support the role of Logo-OD as a positive trigger event for change, no clear empirical evidence was found relating to the impact of a positive organisational context and the notion of framing on the employee's experience of meaning in or at work. It may also be argued that perspectives on meaning outside of the logotherapy school of thought require more consideration.

\section{Future research opportunities}

Flowing from the limitations of this study, further research should be conducted to investigate potential causal linkages between meaning in or at work and organisational change. In this regard, instruments to measure specifically the meaning experience within the work context, rather than meaning in life in general, will be helpful (Burger, 2007). In addition, the role of the components of a positive organisational context and framing based on logotherapeutic principles in promoting the experience of meaning, should be empirically verified. Investigating the concept of work as a calling in relation to organisational change will also provide useful insights into the greater meaning context of work in organisations.

\section{Conclusion}

Although research pertaining to organisational change has flourished since the 1980s and a body of knowledge that is more than 60 years old exists in the fields of organisation development and logotherapy, very little has been written about the meaning context of organisational change or utilising logotherapeutic principles in facilitating such change. This article therefore provided a relatively fresh perspective for framing the change-context relationship. Moreover, specific recommendations were forwarded to leverage this meaning context toward optimising change initiatives.

\section{Acknowledgement Competing interests}

The authors declare that they have no financial or personal relationship(s) which may have inappropriately influenced them in writing this paper.

\section{Authors' contributions}

This article is based on the doctoral research by the first author D.H.B. (University of Johannesburg \& Accenture South Africa). F.C. (University of Johannesburg) and G.R. (University of Johannesburg), respectively the second and third authors, also acted as supervisors for the study and were in this capacity involved in the conceptualisation and writing of this article.

\section{References}

Abel, C.F., \& Sementelli, A.J. (2005). Evolutionary critical theory, metaphor, and organizational change. Journal of Management Development, 24(5), 443-458. http://dx.doi.org/10.1108/02621710510598454

Ahn, M.J., Adamson, J.S.A., \& Dornbusch, D. (2004). From leaders to leadership: Managing change. Journal of Leadership \& Organizational Studies, 10(4), 112-123. $\mathrm{http}: / / \mathrm{dx}$.doi.org/10.1177/107179190401000409

Ambrose, D. (1996). Healing the downsized organization. New York: Harmony.

Armenakis, A.A., Harris, S.G., \& Mossholder, K.W. (1993). Creating readiness for organizational change. Human Relations, 46(6), 681-703. http://dx.doi.org/10.1177/ 001872679304600601

Atkinson, P. (2005). Managing resistance to change. Management Services, 49(1), 14-19.

Avolio, B.J., \& Luthans, F. (2006). The high impact leader: Moments matter in accelerating authentic leadership development, New York: McGraw Hill

Ayers, D.F. (2005). Organizational climate in its semiotic aspect: A postmodern community college undergoes renewal. Community College Review, 33(1), 1-22. http://dx.doi.org/10.1177/009155210503300101

Bartlett, C.A., \& Ghoshal, S. (1994). Changing the role of top management: Beyond strategy to purpose. Harvard Business Review, 72(6), 79-88. 
Bartunek, J.M., Rousseau, D.M., Rudolph, J.W., \& De Palma, J.A. (2006). On the receiving end: Sensemaking, emotion, and assessments of an organizational change initiated end: Sensemaking, emotion, and assessments of an organizational change initiated
by others. The Journal of Applied Behavioral Science; 42(2), 182-206. http://dx.doi. by others. The Journal of Applied
org/10.1177/0021886305285455

Bean, C.J., \& Hamilton, F.E. (2006). Leader framing and follower sensemaking: Response to downsizing in the brave new workplace. Human Relations, 59(3), 321-349. http://dx.doi.org/10.1177/0018726706064177

Bennett, H., \& Durkin, M. (2000). The effects of organisational change on employee psychological attachment: An exploratory study. Journal of Managerial Psychology, 15(2), 126-147. http://dx.doi.org/10.1108/02683940010310328

Bovey, W.H., \& Hede, A. (2001). Resistance to organizational change: the role of defence mechanisms. Journal of Managerial Psychology, 16(7), 534-548. http:// dx.doi.org/10.1108/EUM0000000006166

Burger, D.H. (2007). The applicability of logotherapy as an organisation development intervention. Unpublished doctoral thesis, University of Johannesburg, Johannesburg, South Africa.

Burger, D.H, Crous, F., \& Roodt, G. (2008). Logo-OD: The applicability of logotherapy as an OD intervention. South African Journal of Industrial Psychology, 34(1), 32-41.

Burnes, B. (1996). No such thing as ... a 'one best way' to manage organizational change. Management Decision, 34(10), 11-18. http://dx.doi.org/10.1108/002517 49610150649

Burnes, B. (2003). Managing change and changing managers from $A B C$ to $X Y Z$ Journal of Management Development, 22(7), 627-642. http://dx.doi.org/10.1108/ 02621710310484768

Burnes, B., \& James, H. (1994). Culture, cognitive dissonance and the management of change. International Journal of Operations \& Production Management, 15(8), 14-33. http://dx.doi.org/10.1108/01443579510094062

Byars, L.L., \& Rue, L.W. (2000). Human resource management (6th edn.). Boston, MA: Irwin, McGraw-Hill.

Cappelli, P. (1999). Rethinking employment. In R.S. Schuler, \& S.E. Jackson (Eds.) Strategic human resource management (pp. 282-316). Malden, MA: Blackwell.

Carbery, R., \& Garavan, T.N. (2005). Organisational restructuring and downsizing: Issues related to learning, training and employability of survivors. Journal
of European Industrial Training, 29(6), 488-508. http://dx.doi.org/10.1108/ of European Industrial

Cartwright, S., \& Cooper, G.L. (1994). The human effects of mergers and acquisitions. In G.L. Cooper, \& D.M. Rousseau (Eds.). Trends in organizational behaviour, Vol. 1 (5 Vols) (pp.47-61). New York: Wiley.

Cartwright, S., \& Cooper, G.L. (1995). Organizational marriage: 'hard' versus 'soft' issues? Personnel Review, 24(3), 32-42. http://dx.doi.org/10.1108/00483489510089632

Cascio, W.F. (1998). Applied psychology in human resource management (5th edn.). Upper Saddle River, NJ: Prentice Hall.

Chapman, J.A. (2002). A framework for transformational change in organisations. Leadership and Organization Development Journal, 23(1), 16-25. http://dx.doi. org/10.1108/01437730210414535

Chawla, A., \& Kelloway, E.K. (2004). Predicting openness and commitment to change. Leadership \& Organization Development Journal, 25(6), 485-498. http://dx.doi. org/10.1108/01437730410556734

Chreim, S. (2006). Postscript to change: Survivors' retrospective views of organizational changes Personnel Review, 35(3), 315-335. http://dx.doi.org/10.1108/00483480 610656711

Cooper, N. (2007). How to ... create meaning in the workplace. Personnel Today, May, 29.

Counsell, R., Tennant, C., \& Neailey, K. (2005). The development of a model to support synchronous change. Measuring Business Excellence, 9(3), 13-20. http://dx.doi org/10.1108/13683040510616934

Csikszentmihalyi, M. (1996). Creativity: Flow and the psychology of discovery and invention. New York: Harper Perennial. PMid:8656320

Csikszentmihalyi, M. (1999). If we are so rich, why aren't we happy? American Psychologist, 54, 821-827. http://dx.doi.org/10.1037/0003-066X.54.10.821

Cummings, T.G., \& Worley, C.G. (2001). Organization development and change (7th edn.). Cincinnati, $\mathrm{OH}$ : South-Western College.

Dalton, G.W. (1989). Developmental views of careers in organizations. In M.B. Arthur, D.T Hall, \& B.S. Lawrence (Eds.), Handbook of career theory (pp. 89-109). Cambridge: Cambridge University Press. http://dx.doi.org/10.1017/CBO9780511625459.007

Das, A.K. (1998). Frankl and the realm of meaning. Journal of Humanistic Counseling Education and Development, 36(4), 199-212. http://dx.doi.org/10.1002/j.21644683.1998.tb00392.x

Dollarhide, C.T. (1997). Counseling for meaning in work and life: An integrated approach. Journal of Humanistic Education and Development, 35(4), 178-187. $\mathrm{http}: / / \mathrm{dx}$.doi.org/10.1002/j.2164-4683.1997.tb00368.x

Fabry, J.B. (1987). The pursuit of meaning: Viktor Frankl, logotherapy, and life (Rev. edn.). Berkeley, CA: Institute of Logotherapy Press.

Fabry, J.B. (1988). Guideposts to meaning: Discovering what really matters. Berkeley, CA: Institute of Logotherapy Press.

Fiorito, J., Bozeman, D.P., Young, A., \& Meurs, J.A. (2007). Organizational commitment human resource practices, and organizational characteristics. Journal of Managerial Issues, 19(2), 186-207.

Frances, M. (1995). Organizational change and personal mythology. Personnel Review 24(4), 58-68. http://dx.doi.org/10.1108/00483489510091783

Francis, D., Bessant, J., \& Hobday, M. (2003). Managing radical organisational transformation. Management Decision, 41(1), 18-31. http://dx.doi.org/10.1108/ 00251740310462023
Frankl, V.E. (1967). Psychotherapy and existentialism: Selected papers on logotherapy. New York: Washington Square Press.

Frankl, V.E. (1978). The unheard cry for meaning: Psychotherapy and humanism. New York: Washington Square Press. http://dx.doi.org/10.1037/h0086035

Frankl, V.E. (1984). Man's search for meaning (Rev. edn.). New York: Washington Square Press.

Frankl, V.E. (1986). The doctor and the soul: From psychotherapy to logotherapy (3rd edn.). New York: Random House.

Frankl, V.E. (1988). The will to meaning: Foundations and applications of logotherapy (2nd edn.). New York: Meridian.

Frankl, V.E. (1990). Facing the transitoriness of human existence. Generations, 14(4), $7-11$.

Frankl, V.E. (1992). Meaning in industrial society. The International Forum for Logotherapy, $15,66-70$.

Frankl, V.E. (2000a). Man's search for ultimate meaning. Cambridge, MA: Perseus. PMid:10919734

Frankl, V.E. (2000b). Recollections: An autobiography (J. Fabry \& J. Fabry, Trans.) Cambridge, MA: Perseus. PMid:10919734

Fromm, E. (1976). To have or to be? New York: Harper \& Row.

Fromm, E. (1993). The art of being. London: Constable.

Ghoshal, S., \& Bartlett, C.A. (1996). Rebuilding behavioral context: a blueprint for corporate renewal. Sloan Management Review, 37(2), 23-36.

Gil, F., Rico, R., Alcover, C.M., \& Barrasa, A. (2005). Change-oriented leadership, satisfaction and performance in work groups: Effects of team climate and group potency. Journal of Managerial Psychology, 20(3/4), 312-328. http://dx.doi.org/ 10.1108/02683940510589073

Gini, A.R., \& Sullivan, T. (1993). Work: The process and the person. In T.I. White (Ed.), Business ethics: a philosophical reader (pp. 132-138). New York: MacMillan.

Greenhaus, J.H., Callanan, G.A., \& Godshalk, V.M. (2000). Career management (3rd edn.). Fort Worth, TX: Harcourt Brace.

Greenstein, M., \& Breitbart, W. (2000). Cancer and the experience of meaning: A group psychotherapy for people with cancer. American Journal of Psychotherapy 54(4), 486-500. PMid:11109133

Hacker, M., \& Washington, M. (2004). How do we measure the implementation of large-scale change? Measuring Business Excellence Volume, 8(3), 52-59. http:// dx.doi.org/10.1108/13683040410555618

Hall, D.T. (1996). Implications: The new role of the career practitioner. In D.T. Hall, \& Associates (Eds.), The career is dead, long live the career, a relational approach to careers (pp. 314-336). San Francisco: Jossey-Bass.

Hammer, M. (1996). Beyond reengineering. London: Harper Collins Business.

Hammer, M., \& Champy, J. (1993). Reengineering the corporation: A manifesto for business revolution. London: Nicholas Brealy.

Hart, C. (2005). Doing a Literature Review (5th edn.). London: SAGE.

Havenga, A.A., \& Coetzer, P. (1997). Viktor Frankl the man. In F. Crous, A.A. Havenga, P. Coetzer, \& G. van den Heever (Eds.), On the way to meaning: Essays in remembrance of Viktor Frankl (pp. 11-19). Benmore: Viktor Frankl Foundation of South Africa.

Heil, G., Bennis, W., \& Stephens, D.C. (2000). Douglas McGregor, revisited: Managing the human side of the enterprise. New York: John Wiley.

Heine, S.J, Proulx, T., \& Vohs, K.D. (2006). The Meaning Maintenance Model: on the coherence of social motivations. Personality and Social Psychology Review, 1(2), 88-110. http://dx.doi.org/10.1207/s15327957pspr1002_1

Hellgren, J., Näswall, K., \& Sverke, M. (2005). There's more to the picture than meets the eye: A comparison of downsizing survivors with changed and unchanged
content. South African Journal of Industrial Psychology, 31(4), 87-93. http:// content. South African Journal of

Hergenhahn, B.R. (1997). An introduction to the history of psychology (3rd edn.). Pacific Grove, CA: Brooks/Cole. PMid:9230287

Isaksen, J. (2000). Constructing meaning despite the drudgery of repetitive work. Journal of Humanistic Psychology, 40(3), 84-107. http://dx.doi.org/10.1177/ 0022167800403008

Jime'nez-Jime'nez, D., \& Sanz-Valle, R. (2005). Innovation and human resource management fit: an empirical study. International Journal of Manpower, 26(4), 364-381. http:// dx.doi.org/10.1108/01437720510609555

Johnson, D.M. (2004). Adaptation of organizational change models to the implementation of quality standard requirements. International Journal of Quality \& Reliability Management, 21(2), 154-174. http://dx.doi.org/10.1108/02656710410516961

Karp, T. (2004). Learning the steps of the dance of change: Improving change capabilities by integrating futures studies and positive organisational scholarship. Foresight, 6(6), 349-355. http://dx.doi.org/10.1108/14636680410569920

Kausch, K.D., \& Amer, K. (2007). Self-transcendence and depression among Aids memorial quilt panel makers. Journal of Psychosocial Nursing, 45(6), 45-53.

Kets de Vries, M.F.R. (2001). The leadership mystique: A users manual for the human enterprise. London: Prentice Hall.

Kinnear, C., \& Roodt, G. (1998). The development of an instrument to measure organisational inertia. South African Journal of Industrial Psychology, 24(2), 44-54. http://dx.doi.org/10.4102/sajip.v24i2.652

Kotter, J.P., \& Schlesinger, L.A. (1979). Choosing strategies for change. Harvard Business Review, 57(1), 106-114. PMid:10240501

Lawrence, P.R. (1970). How to deal with resistance to change. In G.W. Dalton, P.R. Lawrence, \& L.E. Greiner (Eds.), Organizational change and development (pp. 181-197). Homewood, IL: Irwin. 
Luthans, F., \& Avolio, B. (2003). Authentic leadership development. In K.S. Cameron, J.E. Dutton \& R.E. Quinn (Eds.), Positive organizational scholarship: Foundations of J.E. Dutton \& R.E. Quinn (Eds.), Positive organizational scholarship:
a new discipline (pp. 241-258). San Francisco, CA: Berret Koehler.

Maitlis, S., \& Sonenshein, S. (2010). Sensemaking in Crisis and Change: Inspiration and Insights From Weick (1988). Journal of Management Studies, 47(3), 551-580. http://dx.doi.org/10.1111/j.1467-6486.2010.00908.x

Markow, F., \& Klenke, K. (2005). The effects of personal meaning and calling on organizational commitment: An empirical investigation of spiritual leadership. The International Journal of Organizational Analysis, 13(1), 8-27. http://dx.doi. org/10.1108/eb028995

Maslow, A.H. (1998). Maslow on management. New York: John Wiley.

May, D., Gilson, R., \& Harter, L. (2004). The psychological conditions of meaningfulness, safety and availability and the engagement of the human spirit at work. Journal of Occupational and Organisational Psychology, 77, 11-37. http://dx.doi.org/10.1348/ 096317904322915892

McGreevy, M. (2003a). Managing the transition. Industrial and Commercial Training, 35(6), 241-246. http://dx.doi.org/10.1108/00197850310493901

McGreevy, M. (2003b). The changing nature of work. Industrial and Commercial Training, 35(5), 191-195. http://dx.doi.org/10.1108/00197850310487322

McGuinness, T., \& Morgan, R.E. (2005). The effect of market and learning orientation on strategy dynamics: The contributing effect of organisational change capability. European Journal of Marketing Volume 39(11/12), 1306-1326. http://dx.doi. org/10.1108/03090560510623271

Moomal, Z. (1999). The relationship between meaning in life and mental well-being. South African Journal of Psychology, 29 (1), 42-48.

Morin, E.M. (1995). Organizational effectiveness and the meaning of work. In T.C. Pauchant \& Associates (Eds.), In search of meaning: Managing for the health of our organizations, our communities, and the natural world (pp. 29-64). San Francisco: Jossey-Bass.

Naidu, J., \& Van der Walt, M.S. (2005). An exploration of the relationship between leadership styles and the implementation of transformation interventions. South African Journal of Human Resource Management, 3(2), 1-10. http://dx.doi. org/10.4102/sajhrm.v3i2.60

Newstrom, J.W., \& Davis, K. (1997). Organizational behavior: Human behavior at work (10th edn.). New York: McGraw-Hill.

Nguyen-Huy, Q. (2000). Do humanistic values matter? Academy of Management Proceedings. Retrieved June 20, 2002, from http://search.epnet.com

Nijhof, W.J., De Jong, M.J., \& Beukhof, G. (1998). Employee commitment in changing organizations: An exploration. Journal of European Industrial Training, 22(6), 243-248. http://dx.doi.org/10.1108/03090599810224701

Pfeifer, T., Schmitt, R., \& Voigt, T. (2005). Managing change: Quality-oriented design of strategic change processes. The TQM Magazine, 17(4), 297-308. http://dx.doi. org/10.1108/09544780510603152

Pratt, A., \& Ashforth, B.E. (2003). Fostering meaningfulness in working and at work. In K.S. Cameron, J.E. Dutton \& R.E. Quinn (Eds.), Positive organizational scholarship: Foundations of a new discipline (pp. 309-327). San Francisco, CA: Barrett Koehler.

Proctor, T., \& Doukakis, I. (2003). Change management: The role of internal communication and employee development. Corporate Communications: An International Journal 8(4), 268-277. http://dx.doi.org/10.1108/13563280310506430

Rashid, M.Z.A., Sambasivan, M., \& Rahman, A.A. (2004). The influence of organizational culture on attitudes toward organizational change. Leadership \& Organization Development Journal, 25(2), 161-179. http://dx.doi.org/10.1108/ Organization Develop

Rifkin, J. (1995). The end of work: The decline of the global labour force and the dawn of the post-market era. New York: J.P. Tarcher.

Robbins, S.P., Odendaal, A., \& Roodt, G. (2003). Organisational behaviour: Global and Southern African perspectives. Cape Town: Pearson Education.

Rossouw, G.J. (2002). Business ethics in Africa. Cape Town: Oxford Southern Africa. http://dx.doi.org/10.1023/A:1015205511601

Rossouw, G.J., \& Bews, N. (2002). Building trust with ethics. In G.J. Rossouw (Ed.), Business ethics in Africa (pp. 145-156). Cape Town: Oxford Southern Africa.

Roxburgh, C. (2003), Hidden flaws in strategy. The McKinsey Quarterly, 2, 26-39.

Saunders, M., Lewis, P., \& Thornhill, A. (2007). Research Methods for Business Student (4th edn.), UK: Pearson Education Ltd, UK.

Schlechter, A.F., \& Engelbrecht, A.S. (2006). The relationship between transformational leadership, meaning and organizational citizenship behaviour. Management Dynamics, 15(4), 2-16.
Scroggins, W.A. (2006). Managing meaning for strategic change: The role of perception and meaning congruence. Journal of Health and Human Services Administration, 29(1/2), 83-103.

Shantall, T. (1989). Viktor Frankl's existential theory. In W.F. Meyer, C. Moore, \& H.G. Viljoen (Eds.), Personality theories - from Freud to Frankl (pp. 421-439). Johannesburg: Lexicon.

Sirkin, H.L., Keenan, P., \& Jackson, A. (2005). The hard side of change management Harvard Business Review, 83(10). Retrieved November 12, 2005, from http:// search.epnet.com

Southwick, S.M., Gilmartin, R., McDonough, P., \& Morrissey, P. (2006). Logotherapy as an adjunctive treatment for chronic combat-related PTSD: A meaning-based intervention. American Journal of Psychotherapy, 60(2), 161-174.

Smith, I. (2005a). Achieving readiness for organisational change. Library Management, 26(6/7), 408-412. http://dx.doi.org/10.1108/01435120510623764

Smith, I. (2005b). Continuing professional development and workplace learning 11: Managing the 'people' side of organisational change. Library Management, 26(3), 152-155. http://dx.doi.org/10.1108/01435120510580898

Steger, M.F., Pickering, N.K., Shin, J.Y., \& Dik, B.J. (2010). Calling in work: Secular or sacred? Journal of Career Assessment, 18, 82-96. http://dx.doi.org/10.1177/ 1069072709350905

Stevenson, L. (1987). Seven theories of human nature (2nd edn.), New York: Oxford University Press.

Tetenbaum, T.J. (1998). Shifting paradigms: From Newton to chaos. Organizational Dynamics, 26(4), 21-32. http://dx.doi.org/10.1016/S0090-2616(98)90003-1

Trader-Leigh, K.E. (2002). Case study: Identifying resistance in managing change. Journal of Organizational Change Management, 15(2), 138-155. http://dx.doi. org/10.1108/09534810210423044

Ugboro, I.O. (2006). Organizational commitment, job redesign, employee empowerment and intent to quit among survivors of restructuring and downsizing. Journal of Behavioral and Applied Management, 7(3), 232-257.

Vakola, M., Tsaousis, I., \& Nikolaou, I. (2004). The role of emotional intelligence and personality variables on attitudes toward organisational change. Journal of Manageria Psychology, 19(2), 88-110. http://dx.doi.org/10.1108/02683940410526082

Viljoen, H.G. (1989). The socially-oriented psycho-analytic theories. In W.F. Meyer, C. Moore, \& H.G. Viljoen (Eds.), Personality theories - from Freud to Frankl (pp. 116-144). Johannesburg: Lexicon.

Wanberg, C.R., \& Banas, J.T. (2000). Predictors and outcomes of openness to changes in a reorganizing workplace. Journal of Applied Psychology, 85(1), 132-142. http://dx.doi.org/10.1037/0021-9010.85.1.132

Washburn, E.R. (1998). The physician leader as logotherapist. Physician Executive, 24 (4), 34-39.

Washington, M., \& Hacker, M. (2005). Why change fails: Knowledge counts. Leadership \& Organization Development Journal, 26(5), 400-411. http://dx.doi.org/10.1108/ 01437730510607880

Watson, G.W. (2003). Ideology and the symbolic construction of fairness in organizational change. Journal of Organizational Change Management, 16(2), 154-168. http://dx.doi.org/10.1108/09534810310468125

Weber, R.J. (2000). The created self: reinventing body, persona, and spirit. New York: Norton.

Worrall, L., \& Cooper, C. (2004). Managers, hierarchies and perceptions: A study of UK managers. Journal of Managerial Psychology, 19(1), 41-68. http://dx.doi. org/10.1108/02683940410520655

Wrzesniewski, A. (2003). Finding positive meaning in work. In K.S. Cameron, J.E. Dutton, \& R.E. Quinn (Eds.), Positive organizational scholarship: Foundations of a new discipline (pp. 296-308). San Francisco, CA: Barrett Koehler.

Wrzesniewski, A., \& Dutton, J.E. (2001). Crafting a job: Revisioning employees as active crafters of their work. Academy of Management Review, 26, 179-201. http:// dx.doi.org/10.5465/AMR.2001.4378011, http://dx.doi.org/10.2307/259118

Wrzesniewski, A., Dutton, J., \& Debebe, G. (2003). Interpersonal sense making and the meaning of work. Research in Organisational Behavior, 25, 95-135. http://dx.doi. org/10.1016/S0191-3085(03)25003-6

Wrzesniewski, A., McCauley, C., Rozin, P., \& Schwartz, B. (1997). Jobs, careers and callings: People's relations to their work. Journal of Research in Personality, 31 21-33. http://dx.doi.org/10.1006/jrpe.1997.2162

Yalom, I.D. (1980). Existential psychotherapy. New York: Basic Books.

Young, A.P. (2000). 'I'm just me': A case study of managerial resistance. Journal of Organizational Change Management, 13(4), 375-388. http://dx.doi.org/10.1108/ 09534810010339068 